\title{
MODEL PEMBELAJARAN PEMAKNAAN PADA MATERI SISTEM ORGANISASI KEHIDUPAN UNTUK MENINGKATKAN HASIL BELAJAR DAN MENUMBUHKAN KARAKTER SISWA SMP
}

\author{
Dewi Markiah ${ }^{1)}$, Rudiana Agustini' ${ }^{2)}$, Toeti Koestiari ${ }^{3)}$ \\ ${ }^{1)}$ Mahasiswa Program Studi Pendidikan Dasar, Program Pascasarjana Universitas Negeri Surabaya \\ ${ }^{2), 3)}$ Dosen Pascasarjana Prodi Pendidikan Sains Univesrtitas Negeri Surabaya \\ E-mail: ayanadewi@gmail.com
}

\begin{abstract}
This study aims to describe the application of meaning learning model in life organizational system material on learning feasibility, student activities, student responses, student learning outcomes (knowledge, skills and attitudes), and development character of discipline and responsibility. Subjects of the research are seventh grade students of SMP 2 Tanah Grogot, Paser district of East Kalimantan academic year 2014/2015. This is Pre-Experimental One Group Pre-test-Post Test Design research. Methods of collecting data in this research are observation, testing, and questionnaires. Technique of data analysis is using descriptive quantitative analysis. Based on the data analysis of the research obtain some findings: a) developed learning materials are generally valid and well categorized, b) observation of study feasibility is well categorized, c) students' activity during the learning is quite active, d) students' response to all learning components are good and positive, e) students learning outcomes on knowledge has increased which can be seen from both individual learning outcomes, skill and attitude learning outcome after the teaching learning process are well done, f) based on the observation, discipline and responsibility character during the teaching learning process has increased well. It is concluded that the application of meaning learning models purport to improve learning outcomes, grow the discipline and responsibility character on seventh grade of junior high school students.
\end{abstract}

\section{Keywords: Meaning Learning Model, Learning Outcomes, Attitude/Character, Life Organizational System}

\begin{abstract}
Abstrak: Penelitian ini bertujuan untuk mendeskripsikan pengaruh model pembelajaran pemaknaan pada materi sistem organisasi kehidupan terhadap peningkatan hasil belajar siswa. Parameter penelitian yang diamati adalah keterlaksanaan pembelajaran, aktivitas siswa, respon siswa, hasil belajar siswa (pengetahuan, keterampilan dan sikap) dan pengembangan karakter disiplin dan tanggung jawab. Subjek penelitian adalah siswa kelas VII SMPN 2 Tanah Grogot Kab. Paser Kalimantan Timur tahun ajaran 2014/2015. Jenis penelitian Pre-Experimental One-Group Pretest-Posttest Design. Metode pengumpulan data menggunakan observasi, tes, dan angket. Teknik analisis data menggunakan analisis deskriptif kuantitatif. Hasil penelitian diperoleh beberapa temuan a) perangkat pembelajaran yang dikembangkan secara umum valid dan berkategori baik, b) keterlaksanaan pembelajaran berkategori baik, c) aktivitas siswa selama proses pembelajaran cukup aktif, d) respon siswa terhadap seluruh komponen pembelajaran baik dan positif, e) hasil belajar siswa aspek pengetahuan terjadi peningkatan pada hasil belajar secara individual, hasil belajar aspek keterampilan dan hasil belajar aspek sikap setelah mengikuti pembelajaran seluruh siswa tuntas, f) pengamatan karakter disiplin dan tanggung jawab selama proses pembelajaran mengalami peningkatan dengan predikat baik. Simpulan hasil penelitian ini bahwa penerapan model pembelajaran pemaknaan dapat meningkatkan hasil belajar dan menumbuhkan karakter disiplin dan tanggung jawab siswa SMP kelas VII.
\end{abstract}

Kata kunci: Model Pembelajaran Pemaknaan, Hasil belajar, Sikap/Karakter, Sistem Organisasi Kehidupan.

\section{PENDAhuluan}

Pemerintah Republik Indonesia melalui Renstra (Rencana Strategis) Kemendiknas (sekarang Kenendikbud) 2010-2014 telah mencanangkan penerapan pendidikan karakter untuk seluruh jenjang pendidikan di Indonesia mulai tingkat Pendidikan Anak Usia Dini (PAUD) sampai Tingkat Perguruan Tinggi (PT) (Listyarti, 2012). Pembangunan karakter yang pada saat ini menjadi salah satu perhatian kuat pemerintah harus disambut baik dan dirumuskan dalam langkah-langkah sistematik dan komprehensif.

Pembangunan karakter bangsa sebagai bagian penting dan tidak terpisahkan dari pembangunan nasional. Kebijakan nasional pembangunan karakter bangsa ini sesuai dengan fungsi dan tujuan pendidikan nasional dalam UU No.20/2003 Pasal 3 tentang Sistem Pendidikan Nasional yang menyebutkan Pendidikan nasional berfungsi mengembangkan kemampuan dan membentuk watak serta peradaban bangsa yang bermartabat dalam rangka mencerdaskan kehidupan 
bangsa. Bertujuan untuk berkembangnya potensi peserta didik agar menjadi manusia yang beriman dan bertakwa kepada Tuhan Yang Maha Esa, berakhlak mulia, sehat, berilmu, cakap, kreatif, mandiri dan menjadi warga negara yang demokratis serta bertanggung jawab (Kemendikbud, 2012)

Tujuan pendidikan nasional ini menjadi dasar dalam mengembangkan pendidikan karakter bangsa karena merumuskan kualitas manusia Indonesia yang harus dikembangkan oleh setiap satuan pendidikan mulai dari pendidikan usia dini sampai pendidikan tinggi. Pendidikan karakter termasuk pencapaian tujuan pembelajaran dalam ranah afektif atau sikap. Masalah afektif dirasakan penting oleh semua orang, namun implementasinya masih kurang. Hasil Identifikasi kesenjangan kurikulum dalam Uji Publik Kurikulum 2013 dijelaskan bahwa kondisi pendidikan kita saat ini pada kompetensi kelulusan: belum sepenuhnya menekankan pendidikan karakter atau sikap, pada penilaian masih menekankan aspek pengetahuan saja, jadi kompetensi belum menggambarkan secara holistik domain sikap, keterampilan dan pengetahuan. Standar penilaian juga belum mengarah pada penilaian berbasis kompetensi (sikap, keterampilan, dan pengetahuan) secara proporsional sehingga tujuan afektif lebih sulit diukur dan merancang pencapaian tujuan pembelajaran afektif tidak semudah seperti pembelajaran kognitif dan psikomotor (Kemendikbud, 2012).

Satuan pendidikan harus merancang kegiatan pembelajaran yang tepat agar tujuan pembelajaran afektif dapat dicapai. Keberhasilan pendidik melaksanakan ranah afektif dan keberhasilan peserta didik mencapai kompetensi afektif perlu dinilai. Penilaian afektif dalam kurikulum 2013 terlihat dari pergeseran penilaian melalui tes (kognitif saja) menuju penilaian otentik (mengukur semua kompetensi sikap, keterampilan dan pengetahuan berdasarkan proses dan hasil). Perangkat penilaian afektif serta penafsiran pengukurannya perlu dikembangkan sesuai dengan kurikulum 2013 dengan memperhatikan adanya keterpaduan antara afektif dan kognitif, dan keterampilan sehingga dapat menghasilkan sumberdaya manusia yang berilmu ilmiah dan berakhlakul karimah (Kemendikbud, 2012).

Keluarga dan sekolah sebagai tempat pengembangan karakter anak, tampaknya sekarang kurang antisipatif terhadap perubahan kultur dan budaya yang melingkupi anak akibat majunya teknologi infomasi. Sehingga tidak heran dewasa ini banyak kejadian menimpa anak dan remaja yang mengindikasikan adanya penurunan kualitas karakter mereka. Naiknya grafik kenakalan/ kriminalitas remaja setiap tahun menunjukkan permasalahan remaja cukup kompleks.
Berdasarkan data yang diakses dari catatan akhir tahun 2013 oleh PP Gema Pembebasan (2013) bahwa Sepanjang tahun 2013 tercatat Sebanyak 19 pelajar tewas sia-sia dalam tawuran antar pelajar di Indonesia. Belasan pelajar itu menjadi korban dari 229 kasus tawuran yang terjadi sepanjang Januari hingga Oktober 2013. Jumlah ini hanya yang diketahui dan belum ditambah dengan jumlah pelajar yang terluka dan dirawat di rumah sakit akibat kekerasan antar sesama pelajar. Demikian data yang dihimpun Komisi Nasional Perlindungan Anak (Komnas PA). Ketua Komnas PA, Arist Merdeka Sirait menyatakan, kasus tawuran yang terjadi sepanjang 2013 meningkat secara drastis dari tahun sebelumnya yang hanya sekitar 128 kasus tawuran. Hal ini menurutnya merupakan indikasi yang membuktikan gagalnya sistem perlindungan terhadap anak di Indonesia. "Banyak pembiaran-pembiaran yang dilakukan oleh negara kita, sehingga anak-anak terus menerus menjadi korban maupun pelaku," kata Arist dalam konferensi pers di Kantor Komnas PA, Jalan TB Simatupang, Pasar Rebo, Jakarta Timur, Rabu (Suara Pembaruan.com - 20/11/2013).

Di Kabupaten Paser Kalimantan Timur berdasarkan data dari guru Bimbingan dan Penyuluhan (BP) tahun 2013 di salah satu SMP di Tanah Grogot Kab. Paser Kalimantan Timur, mulai ditemukan kasuskasus penyimpangan yang dilakukan peserta didik, kasus penyimpangan yang sering dilakukan siswa diantaranya: datang terlambat, bolos sekolah, merokok, buliying, perkelahian sesama teman disekolah atau lain sekolah, melompat pagar, dan lain-lain namun frekuensinya masih sedikit. Adanya kasus perilaku yang menyimpang ini menunjukkan bahwa nilai-nilai moral perlu ditingkatkan di lingkungan sekolah. Nilainilai moral yang ditanamkan ini diharapkan dapat membentuk karakter siswa yang berperilaku baik dalam hidup bermasyarakat. Menurut Lickona (2012), peranan sekolah sebagai tempat pendidikan moral menjadi semakin penting ketika jutaan anak-anak hanya mendapatkan sedikit pendidikan moral dari orang tua mereka dan ketika makna nilai yang sangat berpengaruh yang didapatkan melalui tempat ibadah lainya perlahan tidak berarti dan menghilang dari kehidupan anak-anak.

Permasalahan utama yang terjadi dalam dunia pendidikan kita terutama dalam proses belajar mengajar adalah, sampai saat ini pembelajaran dikelas masih cenderung pada pendekatan teacher learning center, artinya guru adalah pusat pembelajaran, sehingga kegiatan belajar mengajar terasa monoton dan membosankan, efeknya adalah peserta didik cenderung hanya belajar dari satu titik sumber yaitu guru yang menjadikan sempitnya wawasan peserta didik. Efek yang lain adalah kondisi ini mempengaruhi motivasi belajar didik, sehingga peserta didik cenderung lemah 
dalam memahami konsep materi. Model pembelajaran seperti diatas, sangat membatasi kreatifitas berfikir peserta didik, peserta didik juga tidak diberi kesempatan untuk menemukan konsep-konsep dasar dari hasil penemuannya sendiri, peserta didik akan cenderung bersifat individualis karena tidak pernah diajarkan bekerja sama, dan cenderung pasif atau tidak cepat merespon lingkungan. Sehingga timbul dampak negatif yang timbul akibat salah dalam menerapkan model pembelajaran seperti kasus penyimpangan yang sering dilakukan peserta didik seperti dijelaskan diatas.

Bila keadaan ini tidak segera diatasi, dikhawatirkan akan timbul dampak lebih serius, misalnya (a) terjadinya erosi budi pekerti, perilaku baik, dan tingkah laku positif, (b) solidaritas dan kesetiakawanan rendah (frekuensi perkelahian dan tindakan anarkis tinggi), (c) banyak anak berhasil menghapal tapi tidak memahami apa yang mereka hapal, dan pada gilirannya (d) daya saing bangsa menjadi rendah (Ibrahim, 2008). Keadaan seperi ini tentu tidak bisa diabaikan menurut Lickona (2012). pengabaian generasi muda terhadap kepekaan moral dan karakter merupakan sebuah kegagalan yang menuai masalah yang serius menyangkut etika dalam kehidupan bermasyarakat.

Pendidikan budi pekerti atau pendidikan moral sangat diperlukan untuk mengatasi hal ini. Pendidikan budi pekerti atau pendidikan moral merupakan program pengajaran disekolah yang bertujuan mengembangkan watak atau tabiat siswa dengan cara menghayati nilainilai dari keyakinan masyarakat sebagai kekuatan moral dalam hidupnya melalui kejujuran, dapat dipercaya, disiplin dan kerja sama yang menekankan ranah afektif (perasaan dan sikap) tanpa meninggalkan ranah kognitif (berfikir rasional) dan ranah skill/psikomotor (keterampilan, terampil mengolah data, mengemukakan pendapat, dan kerja sama)(Zuriah, 2008).

Berdasarkan keterangan diatas, sangatlah penting peran pendidikan dalam membentuk karakter peserta didik, artinya bahwa proses pendidikan seharusnya tidak hanya sekedar transfer pengetahuan dari seorang guru kepada peserta didik, namun peran guru lebih dari itu, yaitu memastikan perubahan peserta didik dilihat secara kognitif, afektif dan psikomotor, Artinya guru memastikan bahwa peserta didik telah paham terhadap konsep-konsep yang telah diajarkan, sehingga terjadi perubahan cara pandang peserta didik dalam menghadapi masalah, sehingga peserta didik dapat menerapkan konsep yang ia pahami dan memaknainya dalam kehidupan sehari-hari.

Saat ini, telah banyak dikembangkan model-model pembelajaran yang merubah budaya pembelajaran teacher center learning menjadi pembelajaran berbasis student center learning. Variasi model pembelajaran yang diterapkan oleh guru dalam proses pembelajaran akan berpengaruh signifikan terhadap peserta didik. Salah satu model pembelajaran yang dapat diterapkan pada kurikulum 2013 pada pelajaran IPA adalah model pembelajaran pemaknaan, karena model pembelajaran pemaknaan selama ini di rancang hanya sebagai efek penyerta belum dirancang khusus sebagai model pembelajaran yang utama. IPA termasuk ilmu Biologi mencakup beberapa pengertian mendasar yang berkaitan dengan olah karya budi manusia dalam mengungkap alam semesta yang mencakup tiga aspek yang terpadu, yaitu sceintific attitudes (sikap ilmiah), sceintific method (metode ilmiah), dan sceintific product (produk ilmiah). Metode ilmiah dan sikap ilmiah tidak bisa dipisahkan satu sama lain. Sikap ilmiah mencakup kepercayaan, objektif, ingin tahu, jujur, rendah hati, terbuka, teliti, tidak mudah menyerah, kemauan untuk mempertimbangkan fakta baru dan sebagainya yang merupakan nilai positif yang perlu dikembangkan dalam proses pembelajaran.

Berbagai karakter dapat dilatihkan melalui proses belajar IPA. Karakter disiplin dan tanggung jawab perlu dikembangkan karena merupakan karakter dasar utama yang harus dimiliki siswa. Karakter disiplin menunjukkan perilaku tertib dan patuh pada ketentuan dan peraturan dan karakter tanggung jawab adalah sikap dan perilaku seseorang untuk melaksanakan tugas dan kewajibannya, yang seharusnya dia lakukan, terhadap dirinya sendiri maupun orang lain dan lingkungan sekitarnya. Karakter baik diatas dapat dilatihkan dan ditumbuhkan melalui pembelajaran IPA karena sesuai dengan pemaknaan terhadap fenomena pada materi sistem organisasi kehidupan.

Fenomena alam yang sesuai pada materi sistem organisasi kehidupan dapat dijadikan contoh sebagai model dan dimaknai untuk mengembangkan nilai-nilai positif, akhlak mulia dan budi pekerti. Menurut Ibrahim (2008) " Alam menyediakan model yang dapat ditiru oleh siswa dan guru dalam membantu memaknai dan membantu siswa mengaitkan gejala alam dengan sikap positif, akhlakul karimah dan budi pekerti". Sebagai contoh pemahaman pada materi sistem organisasi kehidupan pada bagian sel. Sel adalah bagian terkecil dari tubuh mahkluk hidup yang mampu menjalankan semua fungsi kehidupan, melakukan regulasi terhadap dirinya sendiri, memproses energi, tumbuh dan berkembang, tanggab terhadap lingkungan, serta melakukan reproduksi untuk melestarikan keturunannya. Pemaknaan yang diambil adalah fenomena sel dijadikan "sebagai model" (atau domain analogi) sikap dengan domain target adalah siswa. Perilaku sel yang dianalogikan dengan perilaku manusia yang dapat dijadikan contoh dan ditiru oleh siswa, jadi siswa diharapkan bisa berlaku seperti sel yang mampu 
mengembangkan potensi diri, bersikap disiplin, tanggung jawab, adil, mandiri dan bisa bekerja sama dengan orang lain dan lingkungannya.

Hasil penelitian tentang penerapan model pembelajaran pemaknaan dalam bidang studi IPA di beberapa SD dan SMP menunjukkan bahwa implementasi model pembelajaran pemaknaan mampu menumbuhkan sikap positif, budi pekerti dan akhlakul karimah peserta didik (Ibrahim, 2008). Hasil penelitian Priyono (2013), menunjukkan bahwa penerapan pembelajaran biologi berorientasi pembelajaran pemaknaan dapat digunakan untuk mencapai ketuntasan indikator dan ketuntasan klasikal dalam hasil belajar pengetahuan serta dapat menumbuhkan sikap disiplin dan sikap sensitivitas moral siswa. Begitu juga Pertiwiningrum (2013), hasil penelitiannya menyimpulkan bahwa model pembelajaran pemaknaan pada pokok bahasan sistem reproduksi manusia dapat meningkatkan hasil belajar siswa.

Penerapan model pembelajaran pemaknaan dengan materi organisasi kehidupan, dengan harapan siswa dapat meningkatkan hasil belajar pengetahuan , sikap dan keterampilan serta mengembangkan karaker disiplin dan tanggung jawab dengan memaknai fenomena alam yang terdapat dalam materi organisasi kehidupan.

\section{METODE PENELITIAN}

Jenis penelitian yang digunakan adalah penelitian pra eksperimen yang diawali dengan pengembangan perangkat pembelajaran kemudian diimplementasikan pada siswa dalam proses pembelajaran.

\section{A. Subjek Penelitian}

Subjek Penelitian adalah model pembelajaran pemaknaan pada materi sistem Organisasi Kehidupan dengan sasaran uji coba siswa kelas VII SMPN 2 Tanah Grogot Kab. Paser Kalimantan Timur, dengan jumlah siswa 36 orang.

\section{B. Tempat dan Waktu Penelitian}

Uji coba II dilaksanakan pada semester ganjil tahun ajaran 2014/2015 sebanyak lima kali pertemuan di kelas VII SMP Negeri 2 Tanah Grogot Kab. Paser Kaltim.

\section{Rancangan Penelitian}

Rancangan penelitian yang digunakan dalam penelitian ini adalah one group pretest and posttest design yang dikembangkan oleh Cambell \& Stabley (Arifin, 2002). Rancangan penelitian dapat digambarkan sebagai berikut:

$$
\mathrm{O}_{1} \quad \mathrm{X}^{\mathrm{O}_{2}}
$$

Dengan prosedur berikut:

1. Memberikan uji awal $\left(\mathrm{O}_{1}\right)$, dengan pretes untuk mendapatkan data kemampuan awal siswa sebelum diberikan perlakuan.

2. Memberikan perlakuan (X), dengan penerapan model pembelajaran pemaknaan pada materi Organisasi Kehidupan.

3. Memberikan uji akhir $\left(\mathrm{O}_{2}\right)$, dengan posttest untuk mendapatkan data kemampuan akhir siswa setelah mengikuti kegiatan pembelajaran.

\section{Variabel Penelitian}

Berdasarkan rumusan masalah, maka variabel yang diamati dalam penelitian ini adalah:

1. Keterlaksanaan pembelajaran

2. Aktivitas siswa

3. Hasil belajar pengetahuan dan keterampilan

4. Hasil belajar sikap

5. Respon siswa

\section{E. Prosedur Penelitian}

Prosedur penelitian ini diawali dengan pengembangan perangkat pembelajaran meliputi Rancangan Pelaksanaan Pembelajaran (RPP), Buku ajar Siswa, Lembar Kegiatan Siswa (LKS), Tes Hasil Belajar (THB), Lembar Pengamatan Sikap Siswa, Lembar Pengamatan Keterampilan Siswa, Lembar Pengamatan Aktivitas Siswa dan Angket Respon Siswa. Model Pengembangan perangkat menggunakan model 4-D (Four D Models) yang dikembangkan oleh Thiagarajaan, Semmel dan Semmmel (1974). Tahapan pengembangan model 4-D adalah define (pendefinisian), design (perancangan), develop (pengembangan) dan desseminate (penyebaran). Dalam penelitian ini pengembangan perangkat pembelajaran disederhanakan hanya sampai pada tahap develop tanpa tahap disseminate, sehingga perangkat pembelajaran hanya diimplementasikan pada sekolah ujicoba saja, tanpa disebarkan ke sekolah lain.

\section{F. Instrumen Penelitian}

Instrumen yang dikembangkan dan digunakan dalam penelitian ini adalah:

1. Lembar Validasi Perangkat Pembelajaran

Lembar validasi perangkat pembelajaran digunakan sebagai acuan menilai valliditas perangkat yang dikembangkan pada tahap perencanaan. Validasi perangkat pembelajaran meliputi Validasi Silabus, RPP, BAS, LKS, Tes Hasil Belajar Pengetahuan, Lembar Pengamatan Keterampilan (LPK), Lembar Pengamatan Sikap (LPS), Lembar Aktivitas Siswa (LAS) dan Angket Respon Siswa (ARS). Validasi perangkat dilakukan oleh tiga pakar yang kompeten di bidang pembuatan perangkat pembelajaran. 


\section{Lembar Pengamatan keterlaksanaan RPP}

Instrumen ini digunakan untuk menilai keterlaksanan RPP pada materi Organisasi kehidupan yang berorientasi model pembelajaran pemaknaan yang telah dikembangkan peneliti. Keterlaksanaan RPP berisi langkah-langkah yang harus dilakukan guru dalam proses pembelajaran. Penyajian keterlaksanaan dalam bentuk terlaksana dan tidak terlaksana dengan skor penilaian 1 sampai 4 .

\section{Lembar Pengamatan Aktivitas Siswa}

Lembar pengamatan aktivitas siswa digunakan untuk mengamati aktivitas dan perilaku siswa selama kegiatan belajar mengajar. Observasi dilakukan oleh dua pengamat, dengan mengisi lembar pengamatan aktivitas siswa yang telah disiapkan oleh peneliti.

\section{Lembar Respon Siswa}

Instrumen ini digunakan untuk mengukur pendapat atau respon siswa terhadap kegiatan belajar mengajar. Siswa diminta memberikan tanggapan terhadap perangkat pembelajaran, materi pelajaran, tes hasil belajar, cara guru mengajar dan proses pembelajaran organisasi kehidupan dengan menggunakan model pembelajaran pemaknaan. Hasil respon siswa dinyatakan persentase, dengan rumus:

$$
P=\frac{\Sigma K}{\Sigma^{N}} \times 100 \%
$$

Keterangan :

$\mathrm{P} \quad=$ persentase skor respon siswa

$\sum \mathrm{K}=$ jumlah siswa yang memilih jawaban $\mathrm{Ya}$ atau Tidak

$\sum \mathrm{N}=$ Jumlah siswa yang mengisi angket

\section{Lembar Pengamatan Sikap (Karakter Siswa)}

Pengamatan Sikap atau karakter siswa digunakan untuk mengetahui perubahan karakter siswa selama proses pembelajaran. Karakter yang diamati yaitu disiplin dan tanggung jawab yang disusun berdasarkan indikator yang telah dirumuskan oleh peneliti. Observasi karakter siswa dilakukan oleh dua pengamat dengan mengisi dua lembar observasi karakter siswa pada hasil belajar sikap.

\section{Lembar Pengamatan Keterampilan Siswa}

Lembar pengamatan Keterampilan siswa digunakan untuk mengamati Keterampilan/kinerja siswa selama kegiatan belajar mengajar. Observasi dilakukan oleh dua pengamat, dengan mengisi lembar pengamatan keterampilan siswa yang telah disiapkan oleh peneliti.

\section{Tes Hasil Belajar}

Tes hasil belajar digunakan untuk memperoleh data tentang kemampuan siswa terhadap penguasaan materi sistem organisasi kehidupan setelah dilaksanakan pembelajaran. Tes hasil belajar berupa THB pengetahuan dan THB Keterampilan (kinerja). Tes hasil belajar pengetahuan atas 15 butir soal pilihan ganda dan 5 butir soal uraian atau jawaban singkat, digunakan sebagai pre test dan post test. Selanjutnya soal tes ini dianalisis menggunakan beberapa statistik berikut:

a. Menentukan Reliabilitas Soal

Reliabilitas menunjuk pada satu pengertian bahwa suatu instrumen cukup dapat dipercaya untuk digunakan sebagai alat pengumpul data karena instrumen tersebut baik. Untuk mengetahui reliabilitas soal pilihan ganda pada penelitian ini digunakan rumus KR-20 sebagai berikut:

$$
r_{11}=\left(\frac{n}{n-1}\right)\left(\frac{s_{t}^{2}-\Sigma p_{i} q_{i}}{s_{t}^{2}}\right)
$$

Keterangan:

$$
\begin{aligned}
\mathrm{r}_{11}= & \text { Koefisien Reliabilitas } \\
\mathrm{n}= & \text { Banyaknya butir soal } \\
\mathrm{pi}= & \text { Proporsi banyak subjek yang menjawab } \\
& \text { butir soal ke- } \mathrm{i} \\
\mathrm{q} \mathrm{i}= & \text { Proporsi banyak subjek yang menjawab } \\
& \text { salah butir soal ke- } \mathrm{i}
\end{aligned}
$$

Dimana:

$$
S_{t}^{2}=\frac{\sum X_{t}^{2}-\frac{\left(\sum X_{t}\right)^{2}}{n}}{n}
$$

Keterangan:

$$
\begin{aligned}
& \mathrm{St}^{2}=\text { Varian Skor Total } \\
& \mathrm{Xt}=\text { Jumlah butir soal benar }
\end{aligned}
$$

Sedangkan untuk mengetahui reliabilitas soal uraian digunakan rumus:

$$
r_{11}=\alpha=\left(\frac{n}{n-1}\right)\left(\frac{\sum S_{t}^{2}}{S_{t}^{2}}\right)
$$

(Ratumanan, 2006)

Keterangan: $\quad \sum \mathrm{Si}^{2}=$ Jumlah varian skor Setiap item

Kriteria untuk menginterpretasikan derajat reliabilitas digunakan tabel 1

Tabel 1. Kategori Derajat Reliabilitas Butir Soal

\begin{tabular}{|c|c|}
\hline Koefisien reliabilitas & \multicolumn{1}{|c|}{ Penafsiran } \\
\hline $0,80 \leq \mathrm{r}$ & Derajat reliabilitas tinggi \\
\hline $0,40 \leq \mathrm{r}<0,80$ & Derajat reliabilitas sedang \\
\hline $\mathrm{r}<0,40$ & Derajat reliabilitas rendah \\
\hline
\end{tabular}

(Ornstein, 1990 dalam Ratumanan, 2011) 


\section{b. Sensitivitas Butir Soal}

Selanjutnya butir soal diuji sensitivitas terhadap efek pembelajaran. Besarnya sensitivitas menurut Grounlund (1985) dalam Ibrahim (2005) dapat ditentukan dengan rumus berikut:

Keterangan:

$$
\mathrm{S}=\frac{R a-R b}{T}
$$

$$
\begin{aligned}
& \mathrm{S}=\text { Sensitivitas butir soal } \\
& \mathrm{Ra}=\begin{array}{l}
\text { Jumlah siswa yang menjawab benar pada } \\
\text { uji akhir }
\end{array} \\
& \mathrm{Rb}= \\
& \quad \text { Jumlah siswa yang menjawab benar pada } \\
& \quad \text { uji awal } \\
& \mathrm{T}=\text { Jumlah Siswa yang mengikuti tes }
\end{aligned}
$$

\section{G. Teknik Pengumpulan Data}

Teknik pengumpulan data adalah cara-cara yang dapat digunakan oleh peneliti untuk mengumpulkan data. Pengumpulan data dalam penelitian ini menggunakan teknik berikut:

1. Observasi

2. Pemberian tes hasil belajar

3. Pemberian angket respon siswa

\section{H. Tehnik Analisa Data}

Tehnik analisis data dalam penelitian ini adalah:

1. Analisis validasi Perangkat Pembelajaran

Hasil penilaian terhadap perangkat pembelajaran berupa Silabus, BAS, RPP, LKS, dan THB dianalisis secara deskriptif kualitatif yaitu dengan merata-rata skor masing-masing komponen. Hasil skor rata-rata dideskripsikan sebagai berikut:

Tabel 2. Rentang Skor validasi dan Keterangan

\begin{tabular}{|c|c|l|}
\hline $\begin{array}{c}\text { Rentang } \\
\text { skor } \\
\text { validasi }\end{array}$ & Kesimpulan & \multicolumn{1}{|c|}{ Keterangan } \\
\hline $1.0-1.5$ & Tidak baik & $\begin{array}{l}\text { Belum dapat digunakan, } \\
\text { masih memerlukan } \\
\text { konsultasi }\end{array}$ \\
\hline $1.6-2.5$ & Kurang baik & $\begin{array}{l}\text { Dapat digunakan dengan } \\
\text { banyak revisi }\end{array}$ \\
\hline $2.6-3.5$ & Baik & $\begin{array}{l}\text { Dapat digunakan dengan } \\
\text { sedikit revisi }\end{array}$ \\
\hline $3.6-4.0$ & Sangat baik & Dapat digunakan tanpa revisi \\
\hline
\end{tabular}

\section{Analisis Keterlaksanaan RPP}

Penilaian keterlaksanaan RPP dimulai dari pendahuluan, kegiatan inti, penutup sesuai sintaks model pembelajaran pemaknaan, pengelolaan waktu dan pengelolaan kelas. Penyajian keterlaksanaan dalam bentuk pilihan, yaitu terlaksana dan tidak terlaksana dengan skor penilaian dari 1 sampai 4. Kriteria setiap fase pembelajaran dinilai dengan memberikan tanda $(\sqrt{ })$ pada kolom keterlaksanaan dan pada kolom penilaian
(4: Sangat baik, 3: Baik, 2: Kurang baik, 1: Tidak baik). Tehnik analisis data hasil pengamatan keterlaksanaan RPP secara deskriptif kualitatif. Berdasarkan rata-rata hasil penilaian kedua pengamat untuk setiap aspek yang diamati selanjutnya ditentukan dengan kriteria penilaian sebagai berikut (Ratumanan dan Laurens, 2011):

$$
\begin{aligned}
& 1,00-1,99: \text { Tidak baik } \\
& 2,00-2,99: \text { Kurang baik } \\
& 3,00-3,49: \text { Cukup baik } \\
& 3,50-4,00: \text { Baik }
\end{aligned}
$$

\section{Analisis Aktivitas Siswa}

Aktivitas siswa adalah segala kegiatan yang dilakukan siswa selama pembelajaran berlangsung dan dinilai oleh 2 orang pengamat dengan menggunakan instrument aktivitas siswa yang dipersiapkan peneliti. Data yang diperoleh selanjutnya dianalisis secara deskriptif kuantitatif menggunakan persentilp dengan rumus:

$$
\mathrm{P}=\frac{A}{B} \times 100 \%
$$

Keterangan:

$$
\begin{aligned}
& \mathrm{P}=\text { Persentase aktivitas siswa } \\
& \mathrm{A}=\text { Rata-rata dari dua pengamat } \\
& \mathrm{B}=\text { Jumlah pengamatan }
\end{aligned}
$$

\section{Analisis Respon Siswa}

Angket respon siswa diberikan pada akhir pembelajaran keseluruhan, data respon siswa dianalisis secara deskriptif kuantitatif sehingga diketahui besarnya respon positif atau negative dari siswa selama mengikuti pembelajaran dengan model pemaknaan. Analisis data cangket respon siswa menggunakan skala Guttman. Siswa menjawab Ya bernilai (1) dan siswa menjawab Tidak bernilai (0). Kemudian dianalisis berdasarkan kelompok responden yang menjawab "Ya" dan kelompok responden yang menjawab "Tidak". Secara matematis dapat ditulis sebagai berikut:

$$
P=\frac{\sum K}{\sum N} \times 100 \%
$$

Keterangan:

$$
\begin{aligned}
& \mathrm{P}= \text { Persentase skor respon siswa } \\
& \Sigma \mathrm{K}= \text { Jumlah siswa yang memilih jawaban Ya } \\
& \quad \text { atau Tidak }
\end{aligned}
$$

Persentase respon siswa dikonversi dengan kriteria sebagai berikut:

$$
\begin{aligned}
& \text { Angka } 0 \%-20 \%=\text { Sangat lemah } \\
& \text { Angka } 21 \%-40 \%=\text { Lemah } \\
& \text { Angka } 41 \%-60 \%=\text { Cukup } \\
& \text { Angka } 61 \%-80 \%=\text { Kuat } \\
& \text { Angka } 81 \%-100 \%=\text { Sangat kuat }
\end{aligned}
$$

(Riduwan, 2013). 


\section{Analisis Hasil Belajar Siswa}

Data hasil belajar dianalisis dengan menggunakan deskriptif kuantitatif, yaitu menggunakan tingkat ketuntasan individual yang dinyatakan dengan presentase. Persentase ketuntasan dikonversi untuk mengetahui predikat ketuntasan menggunakan rumus:

$$
\text { Nilai Kompetensi }=\frac{\text { Jumlah Skor yang Diperoleh }}{\text { Skor Maksimum }} \times 4
$$

Tabel 3. Konversi Kompetensi Pengetahuan, Keterampilan dan Sikap

\begin{tabular}{|c|c|c|c|}
\hline \multirow{2}{*}{ Predikat } & \multicolumn{3}{|c|}{ Nilai Kompetensi } \\
\cline { 2 - 3 } & Pengetahuan & Keterampilan & Sikap \\
\hline A & 4 & 4 & \multirow{2}{*}{ SB } \\
\hline A- & 3.66 & 3.66 & \\
\hline B+ & 3.33 & 3.33 & \multirow{2}{*}{ B } \\
\hline B & 3 & 3 & \\
\hline B- & 2.66 & 2.66 & \multirow{2}{*}{ C } \\
\hline C+ & 2.33 & 2.33 & \\
\hline C & 2 & 2 & \multirow{2}{*}{ K } \\
\hline C- & 1.66 & 1.66 & \\
\hline D+ & 1.33 & 1.33 & 1 \\
\hline D & 1 & & 1 \\
\hline
\end{tabular}

(Kemendikbud, PP 81A 2013)

a. Hasil Belajar Pengetahuan

Analisis hasil belajar pengetahuan dilakukan secara deskriptif kuantitatif, yaitu menggunakan tingkat ketuntasan individual yang dinyatakan dengan presentase. Ketuntasan individual dihitung menggunakan rumus berikut ini:

$$
\text { Pindividu }=\frac{\text { Jumlah skor diperoleh Siswa }}{\text { Skor Maksimum }} \times 100 \%
$$

b. Hasil Belajar Keterampilan (Kinerja)

Hasil belajar Keterampilan merupakan nilai keterampilan kinerja siswa dalam menggunakan alat percobaan yang diukur. Penilaian hasil keterampilan kinerja menggunakan rubrik yang dikembangkan. Data yang diperoleh dianalisis secara deskriptif kuantitatif dengan rumus:

$$
\text { Nilai }=\frac{\text { Jumlah skor diperoleh Siswa }}{\text { Skor Maksimum }} \times 100 \%
$$

c. Hasil Belajar Sikap (karakter) Siswa

Hasil belajar sikap merupakan nilai dari observasi dua pengamat tentang pembentukan karakter disiplin dan tanggung jawab siswa selama proses pembelajaran. Penilaian hasil belajar sikap berdasarkan rubrik yang dikembangkan dan sesuai dengan indikator dari karakter yang diteliti. Data yang diperoleh dinyatakan dalam presentase, dianalisis secara deskriptif kualitatif, dengan menggunakan rumus berikut:

$$
\text { Nilai }=\frac{\text { Jumlah skor diperoleh Siswa }}{\text { Skor Maksimum }} \times 100 \%
$$

Nilai hasil tes belajar sikap siswa dikualifikasikan sesuai dengan karakter yang dikembangkan dinyatakan dengan predikat sangat baik (SB), baik (B), Cukup (C) dan kurang (K), sesuai dengan Tabel 4.

Data hasil pretest dan posttest pengetahuan siswa dilakukan analisis N-Gain. N-Gain menunjukkan perbedaan pengetahuan siswa sebelum dan setelah perlakuan.

$$
\langle g\rangle=\frac{\text { Spost }- \text { Spre }}{S \text { max }- \text { Spre }}
$$

Keterangan:

$$
\begin{aligned}
\langle g\rangle & =\text { Nilai gain }, \quad \text { Spost }=\text { Nilai post test } \\
\text { Spre } & =\text { Nilai pre-test }, \text { Smax }=\text { Nilai maksimal }
\end{aligned}
$$

Hasil perhitungan $\mathrm{N}$-gain tersebut kemudian dikonversi dengan kriteria sebagai berikut:

Tabel 4. Kriteria Normalized Gain

\begin{tabular}{|c|c|}
\hline Skor $N$-Gain & Kriteria Normalized Gain \\
\hline $0.70<N$-Gain & Tinggi \\
\hline $0.30 \leq N$-Gain $\leq 0.70$ & Sedang \\
\hline$N$-Gain $<0.30$ & Rendah \\
\hline
\end{tabular}

\section{HASIL PENELITIAN DAN DISKUSI}

Hasil penelitian dengan menggunakan model pembelajaran pemaknaan dapat diuraikan sebagai berikut:

\section{A. Pengembangan Perangkat Pembelajaran}

Perangkat pembelajaran yang dikembangkan berorientasi model pembelajaran pemaknaan, meliputi 1) Silabus, 2) RPP, 3) Buku Ajar Siswa, 4) LKS, 5) Media Pembelajaran dan 6) THB. Keenam perangkat tersebut divalidasi menggunakan instrumen.

\section{B. Instrumen Penelitian yang dikembangkan.}

Tabel 5. Instrumen penelitian yang dikembangkan

\begin{tabular}{|c|l|l|}
\hline No & Instrumen & \multicolumn{1}{|c|}{ Bentuk Instrumen } \\
\hline 1 & $\begin{array}{l}\text { Keteraksanaaa } \\
\text { n RPP }\end{array}$ & $\begin{array}{l}\text { Lembar Pengamatan } \\
\text { Keteraksanaan RPP }\end{array}$ \\
\hline 2 & $\begin{array}{l}\text { Aktivitas } \\
\text { Siswa }\end{array}$ & $\begin{array}{l}\text { Lembar Pengamatan } \\
\text { Aktivitas Siswa }\end{array}$ \\
\hline 3 & $\begin{array}{l}\text { THB } \\
\text { pengetahuan }\end{array}$ & $\begin{array}{l}\text { THB pengetahuan perupa } \\
\text { soal PG dan uraian/jawaban } \\
\text { singkat }\end{array}$ \\
\hline 4 & $\begin{array}{l}\text { THB Pengamatan } \\
\text { Keterampilan }\end{array}$ & $\begin{array}{l}\text { Lembar Seterampilan Siswa } \\
\text { Kerap }\end{array}$ \\
\hline 5 & $\begin{array}{l}\text { Hasil belajar } \\
\text { sikap }\end{array}$ & $\begin{array}{l}\text { Lembar Pengamatan Sikap } \\
\text { Siswa }\end{array}$ \\
\hline 6 & Respon Siswa & Angket Respon Siswa \\
\hline
\end{tabular}




\section{Kualitas Perangkat pembelajaran}

Kualitas perangkat pembelajaran adalah tingkat kelayakan perangkat pembelajaran yang dapat dilihat dari hasil validasi perangkat pembelajaran oleh pakar. Dari hasil validasi perangkat tersebut diperoleh perangkata pembelajaran yang telah dikembangkan memiliki kualitas baik dan dapat digunakan dalam kegiatan pembelajaran.

\section{Keterlaksanaan Perangkat Pembelajaran}

Hasil Pengamatan terhadap keterlaksanaan RPP selama KBM pada pertemuan pertama sampai ketiga untuk implementasi untuk implementasi kelas uji coba dapat dilihat pada Gambar 5.

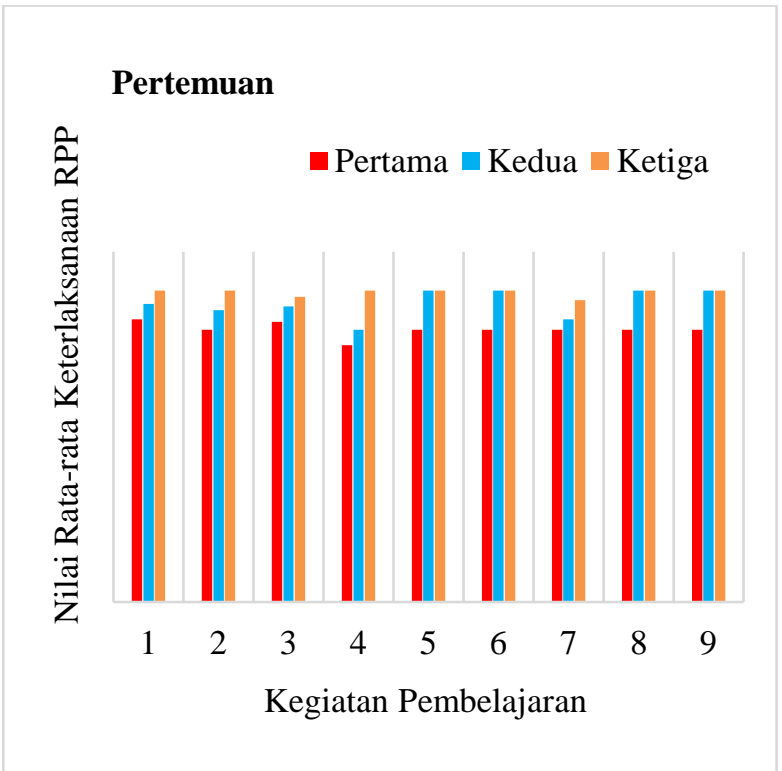

Gambar 5. Hasil Pengamatan Keterlaksanaan RPP

Keterangan:

1.Fase 1 Mengorientasikan siswa masalah atau pertanyaan

2.Fase 2 Merancang proses pemecahan masalah atau menjawab pertanyaan

3.Fase 3 membimbing menyelesaikan masalah atau menjawab pertanyaan

4.Fase 4 Mengkomunikasikan hasil

5.Fase 5 Negoisasi dan konfirmasi

6.Fase 6 Pemaknaan

7.Fase 7 Evaluasi dan refleksi

8.Pengelolaan Kelas

9.Suasana kelas

Hasil analisis data keterlaksanaan RPP pada Gambar 5 dapat dilihat bahwa skor keterlaksanaan RPP berkisar antara 3.5 sampai 4.0. Nilai rata-rata keterlaksanan RPP pada pertemuan 1 sebesar 3.52 dengan kategori baik, pada pertemuan 2 sebesar 3.85 dengan kategori baik dan pada pertemuan 3 sebesar 3.98 dengan kategori baik. Semua tahap kegiatan yang ada di dalam RPP pada uji coba II terlaksana dan skor rata-rata keterlaksanaannya adalah 3.78 dengan kategori baik (Ratumanan dan Laurens, 2011). Instrumen keterlaksanaan RPP mempunyai rata-rata reliabilitas $87.1 \%$, 95\% dan $98.8 \%$ dan berkategori baik (Borich, 1994).

\section{E. Analisis Hasil Pengamatan Aktivitas Siswa}

Aktivitas siswa selama kegiatan belajar mengajar diamati oleh dua orang pengamat. Secara ringkas aktivitas siswa selama pembelajaran pada uji coba II dapat dilihat pada Gambar 6.

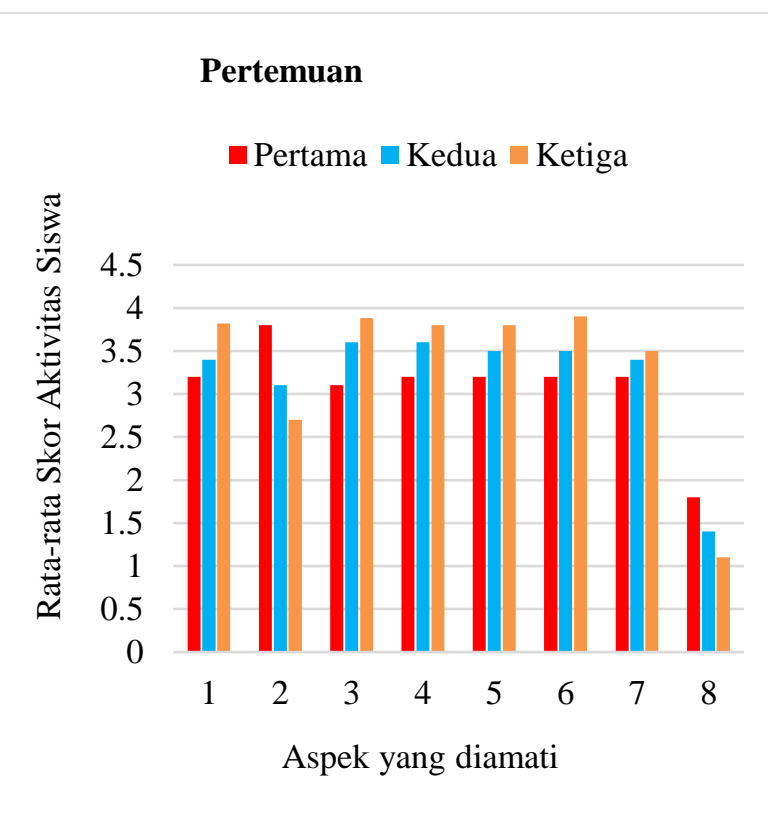

Gambar 6. Hasil Pengamatan Aktivitas Siswa pada Uji Coba II

Keterangan:

1.Membaca buku ajar dan menggarisbawahi ideide penting

2.Bertanya dan mendengarkan penjelasan guru

3.Melakukan pengamatan, eksperimen atau bekerja

4.Mengerjakan tugas atau mengisi LKS

5.Memberi makna pada materi/konsep yang diberikan

6.Melakukan presentasi kelompok

7.Menyampaikan pendapat, berkomunikasi

8.Aktivitas lain yang tidak relevan

Berdasarkan Gambar 6 hasil pengamatan aktivitas siswa menggunakan model pembelajaran pemaknaan untuk meningkatkan hasil belajar pada pertemuan pertama yang paling menonjol sebagai berikut: pada pertemuan pertama adalah bertanya kepada guru dengan rata-rata nilai 3.8. pada pertemuan kedua dan ketiga adalah melakukan kegiatan eksperimen dan mengerjakan LKS sebesar dengan nilai rata-rata 3.6. 
Berdasarkan analisis diperoleh reliabilitas rata-rata hasil

Pengamatan aktivitas siswa pada pembelajaran model pembelajaran pemaknaan adalah pada pertemuan pertama 93,2\%, pertemuan kedua $96.96 \%$, dan pertemuan ketiga $98.02 \%$. Instrumen pengamatan aktivitas mempunyai rata-rata reliabilitas $96.06 \%$ dan berkategori baik (Borich, 1994).

\section{F. Analisis Ketuntasan Hasil Belajar}

Tes hasil belajar pengetahuan digunakan untuk mengetahui hasil belajar siswa yang diukur dari ketuntasan indikator soal yang disesuaikan dengan tujuan pembelajaran. Analisis THB secara berurutan terdiri dari:

\section{Hasil Belajar Pengetahuan}

Hasil analisis data memperlihatkan bahwa pada kegiatan pre test tidak ada siswa yang tuntas. Hal ini di duga karena siswa belum mendapat materi tersebut, walaupun siswa mendapat tugas membaca dari guru pamong yang mengajar materi tersebut. Rata-rata ketuntasan siswa pada pretest sebesar $10.83 \%$ atau dapat dikatakan ketuntasan belajar siswa secara individual masih di bawah kriteria ketuntasan minimal yaitu 70. Pada posttest atau setelah diterapkannya model pembelajaran pemaknaan, jumlah siswa yang dinyatakan tuntas secara individu mengalami peningkatan dengan persentase ketuntasan adalah $85.75 \%$.

Nilai posttest yang diperoleh siswa juga menggambarkan tentang penguasaan materi sistem organisasi kehidupan siswa setelah mengikuti pembelajaran model pemaknaan. Hasil analisis Normalized Gain menunjukkan bahwa siswa yang mengalami peningkatkan hasil belajar dan masuk dalam kriteria tinggi sebesar 94\% dan kategori sedang sebesar $5,55 \%$.

\section{Hasil Belajar Keterampilan}

Hasil belajar keterampilan diperoleh dari pengamatan terhadap kinerja/keterampilan siswa sebelum dan setelah melakukan eksperimen pada kegiatan pembelajaran. Hasil belajar keterampilan pada kelas uji coba II pada saat sebelum dilaksanakan pembelajaran semua siswa tidak tuntas dengan nilai rata-rata 1.0 atau $25 \%$ (predikat D). Hal ini diduga siswa belum pernah membuat preparat dan melakukan pengamatan dengan menggunakan mikroskop. Setelah dilaksanakan pembelajaran diperoleh nilai rata-rata nilai siswa $86.83 \%$ dengan predikat $\mathrm{B}+$ dan nilai rata rata $N$-Gain 0.82. Nilai $N$-Gain menunjukkan bahwa siswa yang mengalami peningkatkan hasil belajar keterampilan dan semua siswa masuk dalam kriteria tinggi (Hake, 1999).

\section{Hasil Belajar Sikap}

Hasil belajar sikap diperoleh dari pengamatan terhadap sikap siswa selama proses pembelajaran. Pengamatan dilakukan oleh dua orang guru pengamat dengan pedoman rubrik penilaian sikap siswa. Hasil analisis data memperlihatkan bahwa hasil belajar sikap pada kelas uji coba II semua siswa tuntas dengan nilai rata-rata 3.6 dengan reliabilitas pengamat pada pertemuan pertama $91.32 \%$, pertemuan kedua $97.58 \%$ dan pertemuan ketiga $98.47 \%$.

\section{G. Hasil Pengamatan Karakter Siswa}

Selama proses pembelajaran dengan menggunakan model pembelajaran pemaknaan pada materi sistem organisasi kehidupan juga dilakukan pengamatan terhadap perilaku berkarakter siswa. Pengamatan terhadap perilaku berkarakter dilakukan pada setiap pertemuan. Pengamatan dilakukan dengan menggunakan lembar pengamatan sikap dan karakter siswa dan berpedoman pada rubrik penilaian sikap atau karakter yang sudah disiapkan oleh peneliti. Karakter yang diamati meliputi karakter disiplin dan tanggung jawab.

\section{Karakter Disiplin}

Hasil analisis data memperlihatkan bahwa karakter disiplin pada uji coba II menunjukkan jumlah siswa yang mendapat predikat SB sebesar $33.3 \%$ dan siswa yang mendapat predikat B sebesar $66.66 \%$. Reliabilitas pengamatan masing-masing pertemuan adalah $89.5 \%, 99.46 \%$ dan $98.51 \%$.

2. Karakter Tanggung Jawab

Berdasarkan analisis data memperlihatkan bahwa karakter tanggung jawab pada uji coba II menunjukkan jumlah siswa yang mendapat predikat sangat baik (SB) sebesar $52.77 \%$ dan mendapat predikat baik (B) $47.22 \%$, dengan reliabilitas pengamat pada masing-masing pertemuan pertama $89.1 \%$, pertemuan kedua $93 \%$ dan pertemuan ketiga $100 \%$.

\section{H. Respon Siswa}

Berdasarkan analisa data diperoleh hasil analisis respon siswa terhadap pengembangan perangkat pembelajaran yaitu (yang meliputi: buku ajar siswa dan lembar kegiatan siswa) dan pelaksanaan pembelajaran dengan suasana mengajar dan cara guru mengajar dengan model pembelajaran pemakanaan pada uji coba II didapatkan hasil bahwa siswa merespon positif (tertarik) sebesar $91.67 \%$ dengan kategori sangat kuat dan yang merespon negatif (tidak tertarik) hanya $8.34 \%$ , Siswa merasa baru dengan perangkat pembelajaran (BAS dan LKS) dan pelaksanaan pembelajaran dengan merespon positif sebesar $88.44 \%$ dan siswa yang merespon negatif $10.56 \%$. 
Siswa juga mudah memahami perangkat pembelajaran (BAS dan LKS) dan pelaksanaan pembelajarannya dengan merespon positif sebesar $88.32 \%$ dan siswa yang merasa kesulitan merespon negatif sebesar $11.68 \%$. Dari hasil analisa data pada Tabel 4.24 dapat dilihat siswa juga mudah memahami dan mengikuti kegiatan pembelajaran dengan model pembelajaran pemaknaan dengan merespon positif sebesar $88.9 \%$ dengan kategori sangat kuat dan yang merespon negatif hanya $11.1 \%$ dengan kategori sangat lemah. Siswa juga merespon positif dengan menyatakan tertarik apabila materi sistem organisasi kehidupan diajarkan dengan model pembelajaran pemaknaan dan tertarik jika topik selanjutnya juga diajarkan dengan menggunakan model ini. Hal ini dapat dilihat dari besar respon positif sebesar $94.4 \%$ kategori sangat kuat dan yang tidak tertarik hanya 5.56\% dengan kategori sangat lemah. Pada penjelasan dan bimbingan guru saat melakukan eksperimen atau pengamatan, siswa juga merespon positif sebesar 94.45\% kategori sangat kuat dan yang merespon negatif hanya 5.55\% kategori lemah. Demikian juga respon siswa terhadap butir soal yang diujikan pada saat post tes siswa merespon positif sebesar $86.1 \%$ kategori kuat dan yang merespon negatif hanya $13.9 \%$ kategori lemah (Riduwan, 2013).

\section{Keterlaksananaan Rencana Pelaksanaan Pembelajaran}

Keterlaksanaan penggunaan perangkat pembelajaran diamati oleh dua orang pengamat. Pengamatan dilakukan selama 3 kali pertemuan yang merupakan implementasi dari RPP sel, jaringan, organ dan sistem organ. Semua tahap-tahap kegiatan yang ada di dalam RPP pada uji coba II terlaksana dan skor keterlaksanaannya pada pertemuan 1 rata-rata 3.52, pertemuan 2 rata rata skor 3.85 dan pertemuan 3 ratarata 3.98, semua dengan kategori Sangat baik (Ratumanan dan Laurens, 2011). Instrumen keterlaksanaan RPP mempunyai rata-rata reliabilitas $87.1 \%$, 95\% dan $98.8 \%$ semua berkategori baik (Borich, 1994). Hasil tersebut menunjukkan bahwa rencana pelaksanaan pembelajaran dengan model pembelajaran pemaknaan pada materi sistem organisasi kehidupan dapat terlaksana dengan baik sesuai dengan RPP yang dikembangkan.

Kualitas keterlaksanaan RPP berada pada kategori baik dan sangat baik, kategori ini diperoleh dengan penjelasan berikut. Pada pertemuan I, semua sintak pada model pembelajaran pemaknaan terlaksana dengan baik, hanya saja ada beberapa kendala dalam proses pelaksanaannya yaitu: 1) pada sintak yang ketiga yaitu Fase 3 membimbing menyelesaikan masalah atau menjawab pertanyaan sedikit mengalami kendala yaitu pada proses pelaksanaan ekperimen/pengamatan karena pada RPP 1a ini ada dua kegiatan pengamatan yaitu kegiatan I pengamatan sel tumbuhan dan kegiatan II pengamatan hewan, yang lakukan untuk mengetahui bagaimana bentuk sel dan membedakan sel tumbuhan dan sel hewan, peneliti selaku guru yang melaksanakan RPP mengalami sedikit kesulitan dalam membimbing karena siswa masih baru atau belum pernah membuat preparat basah, sehingga perlu bimbingan cara penggunaan alat dan cara pengamatan dalam melakukan kegiatan penyelidikan. Selain itu kesulitan manajemen pengaturan waktu agar semua kegiatan dapat terlaksana dengan baik, peneliti membimbing dan memotivasi siswa untuk berbagi tugas dengan teman sekelompoknya untuk lebih cepat dalam membuat preparat, mengamati, menggambar hasil pengamatan, sehingga sintak-sintak selanjutnya dapat terlaksana dengan baik sesuai dengan waktu yang alokasikan. 2) pada pada sintak yang keempat yaitu fase 4 mengkomunikasikan hasil siswa mengalami kendala dalam mempresentasikan hasil pengamatannya, hal ini diduga siswa belum terbiasa dan terlatih dalam mempresentasikan hasil diskusi atau pengamatan. 3) pada sintak yang keenam atau fase 6 pemaknaan siswa masih bingung dan belum paham mencari makna lain selain makna yang telah ada pada konsep, sehingga masih perlu bimbingan guru dalam mencari makna yang dimaksud. Hal ini diduga karena model pembelajaran pemaknaan belum pernah diterapkan di sekolah tersebut sehingga merupakan model pembelajaran baru bagi mereka.

Implementasi RPP 1b materi jaringan pada pertemuan II memperlihatkan semua sintak dalam model pembelajaran pemaknaan dapat terlaksana dengan baik, tidak terdapat masalah yang berarti, siswa mulai menunjukkan peningkatan dalam setiap kegitan pembelajaran, pengelolaan waktu dan suasana kelas juga lebih baik dari dari pada pada saat pelaksanaan RPP 1a, hal ini diduga peneliti selaku guru lebih siap dan siswa sudah sudah mulai mengerti dan paham model pembelajaran ini. Pada Pertemuan III yaitu implementasi dari RPP 1c, semua sintak-sintak dalam model pembelajaran pemaknaan dapat terlaksana dengan baik, siswa semakin aktif dalam mengikuti proses pembelajaran, mereka mulai terbiasa berbagi tugas dengan teman dalam melakukan pengamatan, berdiskusi dengan teman, mempresentasikan hasil pengamatannya dan memberi makna pada konsep yang diberikan. Keterlaksanaan yang semakin baik pada pertemuan yang ketiga ini karena kendala-kendala yang dihadapi pada pertemuan-pertemuan sebelumnya diperbaiki dan diantisipasi oleh peneliti.

Keterlaksanaan RPP pada proses belajar mengajar terlaksana dengan baik karena didukung ketersediaan 
perangkat pembelajaran yang dikembangkan yaitu silabus, RPP, Buku Ajar Siswa, LKS dan media pembelajaran berupa slide power point (PPT). Hal ini sesuai dengan pendapat Ibrahim (2002) menyatakan bahwa guru yang akan "bertempur" di kelas memerlukan sejumlah piranti/perangkat pembelajaran. Piranti tersebut akan membantu dan memudahkan proses belajar mengajar (PBM) untuk mencapai tujuan yang sudah ditentukan. Selain kelengkapan perangkat pembelajaran, tersedianya sarana dan prasarana di sekolah tempat uji coba. Perencanaan yang matang membuat keterlaksanaan RRP berjalan dengan baik sesuai dengan tujuan pembelajaran.

\section{J. Aktivitas Siswa Selama Proses Pembelajaran}

Hasil pengamatan aktivitas siswa pada uji coba II diketahui bahwa ada aktivitas: (1) Membaca buku ajar dan menggarisbawahi ide-ide penting, (2) bertanya dan mendengarkan penjelasan guru, (3) melakukan pengamatan, eksperimen atau bekerja, (4) mengerjakan tugas atau mengisi LKS, (5) memberi makna pada materi/konsep yang diberikan, (6) Melakukan presentasi kelompok, (7) menyampaikan pendapat, berkomunikasi, (8) aktivitas lain yang tidak relevan ada yang mengalami peningkatan dan ada yang mengalami penurunan di setiap pertemuan.

Berdasarkan pengamatan aktivitas yang dilakukan, pada pertemuan pertama siswa lebih aktif pada aktivitas bertanya dan mendengarkan penjelasan guru, diduga siswa merasa baru dan belum mengerti cara-cara membuat preparat, melakukan pengamatan dan cara mengisi LKS dan lain-lain sehingga guru banyak memberi penjelasan dan membimbing siswa. Aktivitas bertanya ini mengalami penurunan pada pertemuan kedua dan ketiga, hal ini di duga siswa mulai paham dan mengerti hal-hal yang harus dilakukan dalam proses pembelajaran pemaknaan.

Aktivitas lain seperti, aktivitas membaca dan menggarisbawahi ide-ide penting, melakukan pengamatan dan mengerjakan LKS, memberi makna pada konsep yang diberikan dan melakukan presentasi dan komunikasi juga terlihat aktif dan terlihat mengalami peningkatan dari pertemuan pertama sampai ketiga, hal ini diduga karena siswa merasa baru dan tertarik untuk mengikuti proses pembelajaran dengan model pembelajaran pemaknaan. Aktivitas-aktivitas ini dilakukan siswa karena dalam model pembelajaran pemaknaan pada sintak yang ketiga yaitu membimbing menyelesaikan masalah atau menjawab pertanyaan ada kegiatan ekperimen atau pengamatan, siswa diduga senang saat melakukan ekperimen dalam hal ini membuat preparat basah dan mengamati preparat dengan mikroskop bagi mereka ini merupakan hal baru yang belum pernah dilakukan, sehingga dalam melakukan eksperimen antusiasme siswa sangat tinggi, hal ini juga berdampak pada aktivitas-aktivitas yang lain. Sedangkan aktivitas perilaku yang tidak relevan semakin jarang dilakukan oleh siswa hal ini dapat dilihat pada pada hasil pengamatan aktivitas siswa . Dengan jarangnya perilaku yang tidak relevan dilakukan mengindikasikan bahwa suasana kelas lebih berpusat pada kegiatan pembelajaran. Adapun perilaku yang tidak relevan yang dilakukan siswa diantaranya bermain-main dengan alat-alat eksperimen, menggangu teman yang mendengarkan guru. Perilaku-perilaku yang tidak relevan tersebut dapat diatasi oleh guru dengan memperingatkan siswa untuk lebih disiplin dan bertanggung jawab dalam kegiatan pembelajaran.

Hal ini sesuai dengan teori belajar perilaku Pavlov dan BF.Skinner, bahwa perilaku berubah sesuai dengan konsekuensi-konsekuensi langsung dari perilaku tersebut (Slavin, 2011). Pemaknaan merupakan contoh cara menunjukkan konsekuensi perilaku yang dilakukan dengan berbagai cara untuk menyentuh hati siswa bahwa apa yang dilakukan oleh sesorang layak untuk ditiru atau patut untuk dihindari (Ibrahim, 2008).

\section{K. Hasil Belajar Siswa}

1. Hasil Belajar Aspek Pengetahuan Siswa

Penelitian ini dilakukan tes sebanyak dua kali yaitu, pre test (uji awal) dan post test (uji akhir). Nilai post test yang diperoleh siswa menggambarkan tentang hasil belajar pengetahuan siswa setelah mengikuti pembelajaran model pembelajaran pemaknaan. Nilai pre test digunakan untuk mengetahui kemampuan awal siswa. Berdasarkan analisis data pada kegiatan pre test semua siswa tidak tuntas. Hal ini dimungkinkan siswa belum menguasai benar materi sistem organisasi kehidupan. Pada post test atau setelah diterapkannya model pembelajaran pemaknaan, baik jumlah siswa yang dinyatakan tuntas secara individu $85.75 \%$. Pada post test ada satu siswa yang belum tuntas. Secara keseluruhan ketidaktuntasan tersebut dimungkinkan siswa belum menguasai benar materi tersebut dan belum terbiasa menggunakan konsep yang sudah dipelajari untuk menyelesaikan soal-soal yang berkaitan dengan materi sistem organisasi kehidupan. Hal ini mungkin terjadi karena siswa tersebut merespon negatif terhadap kegiatan pembelajaran dan merasa kesulitan dengan lembar THB pengetahuan. Selain itu, berdasarkan pengamatan pada saat proses pembelajaran berlangsung guru diharapkan lebih meningkatkan kemampuan dalam mengelola pembelajaran serta lebih banyak memberikan soal-soal sebagai latihan agar siswa terbiasa dengan soal pada materi sistem organisasi kehidupan dan dapat menyelesaikannya dengan benar.

Hasil dari penelitian ini yang dianalisis menggunakan analisis Normalized Gain menunjukkan 
bahwa siswa yang mengalami peningkatan hasil belajar dan masuk dalam kriteria tinggi sebesar $94.4 \%$ dan kategori sedang sebesar 5,55\% (Hake, 1999). Peningkatan yang ditunjukkan oleh hasil analisis dengan menggunakan N-Gain ini menunjukkan tentang penerapan model pembelajaran pemaknaan pada materi sistem organisasi kehidupan efektif dalam meningkatkan penguasaan aspek pengetahuan. Hasil diperkuat dengan hasil penelitian Yuliani (2012), Priyono (2013), dan Pertiwiningrum (2013) yang menyatakan bahwa pembelajaran dengan menggunakan model pembelajaran pemaknaan dapat meningkatkan hasil belajar siswa.

\section{Hasil Belajar Aspek Keterampilan}

Berdasarkan analisis data, hasil belajar keterampilan pada kelas uji coba II didapatkan semua siswa tidak tuntas pada saat tes kinerja sebelum dimulai proses pembelajaran dengan nilai rata-rata 1.00 atau $25 \%$ dengan predikat $\mathrm{D}$, diduga siswa masih belum mahir dan terlatih dalam melakukan kinerja dan pengamatan dengan menggunakan mikroskop hal ini diduga karena siswa masih baru atau asing ketika membuat preparat basah dan penggunaan mikroskop, sehingga pekerjaannya tidak selesai dan tidak dilakukan dengan benar. Setelah proses pembelajaran ketuntasan hasil belajar keterampilan yang diperoleh dengan nilai rata-rata 3.47 atau $86.83 \%$ dengan predikat $\mathrm{B}+$. Hasil belajar ini menunjukan bahwa siswa mulai menguasai keterampilan membuat preparat dan melakukan pengamatan dengan mikroskop walaupun dalam proses pembelajaran siswa banyak mendapat bimbingan guru. Sesuai dengan pendapat Vigotsky dalam Ibrahim (2008), bila seseorang belajar dengan berinteraksi dengan orang lain yang lebih tahu, akan terjadi proses scaffolding.

Proses scaffolding adalah proses bimbingan yang diberikan oleh seseorang yang lebih tahu, misalnya guru atau teman kepada yang kurang tahu yang mula-mula diberikan secara ketat, selanjutnya berangsur-angsur berkurang akhirnya tanggung jawab diambil alih oleh siswa yang belajar. Hasil belajar keterampilan kemudian dianalisis dengan $\mathrm{N}$-Gain diperoleh rata-rata kenaikan nilai $N$-Gain sebesar 0.82 dengan kriteria tinggi (Hake, 1999). Hal ini menunjukkan bahwa penerapan dari perangkat pembelajaran IPA model pembelajaran pemaknaan pada materi sistem organisasi kehidupan efektif dalam meningkatkan penguasaan aspek keterampilan siswa. Sesuai dengan pendapat Ibrahim (2008) bahwa model pemaknaan ini dilatarbelakangi model pembelajaran langsung yang dirancang dengan sengaja untuk mengajarkan keterampilan psikomotorik dan pengetahuan terstruktur dengan baik dan diajarkan tahap demi tahap.

\section{Hasil Belajar Aspek Sikap}

Hasil belajar aspek sikap siswa diperoleh dari pengamat sikap siswa selama pembelajaran yang meliputi sikap religi dan sikap sosial siswa. Sikap religi yang diamati selama pembelajaran adalah rasa syukur. Sikap sosial yang diamati adalah disiplin, bertanggungjawab, dan komunikasi. Nilai rata-rata hasil belajar sikap dari 36 siswa yang teramati selama pembelajaran dalam tiga pertemuan adalah 3.6 dengan kategori baik (B) (Kemendikbud, 2013). Hal ini mengindikasikan bahwa pembelajaran model pembelajaran pemaknaan dapat mengembangkan rasa syukur, sikap disiplin, sikap tanggung jawab dan komunikasi siswa meskipun tidak berkembang secara drastis karena hanya dilaksanakan selama tiga kali pertemuan. Dari hasil analisa data terlihat siswa terus-menerus memperlihatkan sikap yang dinyatakan dalam indikator secara konsisten yang ditunjukan dengan skor perkembangan yang mengalami kenaikan setiap pertemuan melalui penilaian oleh pengamat.

Berdasarkan pengamatan sikap siswa selama pembelajaran tergolong berkembang dengan tidak ada nilai sikap siswa yang masuk dalam kategori kurang dan sikap ini meningkat seiring dengan makin seringnya pertemuan dalam proses pembelajaran. Hal ini sesuai dengan pendapat Sanjaya (2010), bahwa hasil belajar sikap tampak dalam bentuk kemauan, minat, perhatian, perubahan perasaan dan lain-lain. Sikap dapat diubah melalui proses belajar. Belajar bukanlah sekedar mengumpulkan pengetahuan. Belajar adalah proses mental yang terjadi dalam diri seseorang, sehingga menyebabkan munculnya perubahan perilaku. Aktivitas mental itu terjadi karena adanya interaksi individu dengan lingkungan yang disadari.

\section{Karakter Yang Diamati}

Pada penelitian ini ada dua sikap yang sengaja dilatihkan dan diharapkan menjadi karakter yang melekat pada siswa. Karakter yang dilatihkan tersebut adalah disiplin dan tanggung jawab.

1. Disiplin

Berdasarkan hasil analisa data pengamatan sikap/karakter disiplin menunjukkan bahwa dari pertemuan pertama hingga ketiga mengalami kenaikan dari nilai rata-rata 3.35 menjadi 3.72. Sikap disiplin siswa selama melaksanakan pembelajaran dengan model pembelajaran pemaknaan dengan nilai rata-rata 3.51 selama tiga pertemuan dengan kategori baik (B) (Kemendikbud, 2013).

Pada pertemuan pertama ada lima orang siswa yang masih terlambat atau tidak tepat waktu dalam menyelesaikan tugas pengamatan dan tugas menggambar hasil pengamatan sehingga menyebabkan kelompoknya terlambat mengumpulkan tugas LKS, 
Kemudian pada akhir pembelajaran guru mengingatkan agar siswa dapat berbagi tugas dan saling membantu jika teman ada yang kesulitan anggota kelompok lain wajib membantu.

Selain itu mengingatkan siswa dengan mengaitkan pelajaran yang diberikan dengan pemaknaan yang terdapat pada LKS yaitu untuk lebih disiplin dengan tugas-tugas yang diberikan padanya agar tidak merugikan diri sendiri dan teman-temannya. Pada pertemuan selanjutnya semua mulai menunjukkan peningkatan disiplin dengan mengumpulkan tugas tepat pada waktunya. Sesuai dengan pendapat sosiolog, Emile Durkheim dalam Lickona (2012), dalam penelitiannya, bahwa disiplin memungkinkan untuk diterapkan ke dalam lingkungan kelas yang kecil menuju sebuah fungsi yang berguna. Hal ini mengindikasikan bahwa dengan menggunakan model pembelajaran pemaknaan siswa dapat lebih disiplin selama proses pembelajaran. Hal ini juga didukung oleh pendapat Hergenhahn \& Olson (2009) dalam Kesuma dkk (2013), bahwa dalam pendidikan karakter dalam hal ini perilaku karakter disiplin dapat terbangun melalui proses belajar, bukan suatu kebetulan.

\section{Tanggung Jawab}

Berdasarkan analisis data pada sikap/karakter tanggung jawab menunjukkan bahwa dari pertemuan pertama hingga ketiga mengalami kenaikan dari nilai rata-rata setiap pertemuan yaitu 3.4 menjadi 3.8. Sikap tanggung jawab siswa selama melaksanakan pembelajaran dengan model pembelajaran pemaknaan dengan nilai rata-rata 3.63 dengan kategori baik (B) (Kemendikbud, 2013).

Dari pertemuan pertama sampai pertemuan yang ketiga dari data hasil pengamatan pada sikap/karakter tanggung jawab tidak ditemukan siswa yang tidak melaksanakan tugasnya, $100 \%$ siswa melaksanakan tangung jawabnya dengan baik. Ini mengindikasikan bahwa siswa mulai meningkatkan sikap tanggung jawab dengan berupaya menyelesaikan tugasnya. Walaupun pada pertemuan pertama ditemukan pada akhir kegiatan pengamatan, alat dan bahan ada yang belum dikembalikan ketempat semula sehingga perlu diingatkan oleh guru.

Kemudian guru pada akhir pelajaran banyak mengingatkan siswa untuk melaksanakan tugasnya masing-masing dalam kelompok dan guru mengingatkan agar bertanggung jawab dengan apa yang kita lakukan termasuk mengembalikan alat dan bahan yang kita pinjam sesuai dengan pemaknaan pada materi sistem organisasi kehidupan. Pada pertemuan kedua dan ketiga semua siswa terlihat lebih bertanggung jawab dengan tugasnya dan mengembalikan alat dan bahan yang mereka pinjam.
Hal ini mengindikasikan bahwa dengan menggunakan model pembelajaran pemaknaan siswa dapat lebih bertanggung jawab selama proses pembelajaran.

Peningkatan sikap disiplin dan tanggung jawab ini tidak lepas dari pembelajaran sikap yang sengaja didesain dalam model pembelajaran pemaknaan. Hal ini sesuai dengan pendapat Sanjaya (2012), bahwa pembelajaran sikap seseorang dapat dilakukan melalui proses pembiasaan (conditioning) dan melalui proses modelling, yaitu pembentukan sikap melalui proses asimilasi dan mencontoh, dalam hal ini model yang dicontoh adalah fenomena-fenomena IPA yang terdapat dalam materi sistem organisasi kehidupan.

Kegiatan pembelajaran dengan model pembelajaran pemaknaan mulai dari tahap awal sampai akhir dan memberi makna pada konsep yang telah dipelajari dalam proses dan setelah mengikuti kegiatan pembelajaran diharapkan dapat memberi pengalaman belajar dan karakter yang diinginkan yaitu disiplin dan tanggung jawab dapat terbangun dan terlatih. Latihan berkarakter yang baik ini tidak hanya sampai di materi sistem organisasi kehidupan saja, tetapi tetap dilanjutkan terus sampai pada materi-materi selanjutnya, sehingga karakter baik tertanam di dalam diri siswa. Sesuai dengan pendapat Hergenhahn dan Olson (2009) dalam Kesuma dkk (2013) bahwa perubahan perilaku (atau potensial behavioral) berasal dari pengalaman dan latihan.

\section{Respon Siswa}

Berdasarkan hasil analisis dapat diketahui bahwa respon siswa terhadap pengembangan perangkat dan penerapan pembelajaran model pembelajaran pemaknaan selama uji coba II adalah positif dengan nilai $90.47 \%$ kategori sangat kuat. Hal ini berarti siswa mendukung, merasa senang, dan tertarik terhadap pembelajaran dengan menggunakan perangkat model pembelajaran pemaknaan untuk meningkatkan hasil belajar siswa berupa pengetahuan, sikap dan keterampilan. Hasil ini sesuai dengan hasil penelitian dari Sartika (2011) dan Pertiwiningrum (2012) yang menyatakan bahwa dengan menggunakan model pembelajaran pemaknaan untuk meningkatkan hasil belajar dan sensitivitas moral mendapatkan respon positif dari siswa.

\section{KESIMPULAN}

Berdasarkan hasil analisis, diskusi, dan pembahasan, maka disimpulkan bahwa model pembelajaran pemaknaan pada materi sistem organisasi kehidupan dapat meningkatkan hasil belajar dan menumbuhkan karakter baik pada siswa SMP kelas VII. 
Beberapa saran dapat dikemukakan oleh peneliti berdasarkan penelitian yang telah dilakukan adalah sebagai berikut:

1. Penerapan rencana pelaksanaan pembelajaran sudah baik namun guru harus dapat mengelola waktu selama pembelajaran agar pembelajaran bisa berjalan lebih efektif dan efisien.

2. Guru perlu melatih siswa cara penggunaan alat dan cara pengamatan dalam melakukan kegiatan penyelidikan. Pengenalan awal bisa dilakukan pada waktu khusus, agar saat proses pembelajaran berjalan sesuai dengan perencanaan.

3. Model pembelajaran pemaknaan mengintegrasikan sceintific aproach dengan proses pemodelan sikap melalui strategi pemaknaan dan analogi dapat mendidik sikap sebagai domain target, sehingga model pembelajaran ini sangat cocok diterapkan pada kurikulum 2013, diharapkan ada penelitian lanjutan pada materi materi IPA yang lain dan mengembangkan sikap-sikap ilmiah yang lain yang sengaja di desain pada model pembelajaran ini.

\section{REFERENSI}

Arifin, Z. (2002). Metodologi penelitian pendidikan filosofi, teori, dan aplikasinya. Surabaya: Lentera Cendikia.

Borich, G. (1994). Observation skill for effective teaching. New York: Mac Millan Publishing Company.

GemaPembebasan(2013). http://gemapembebasan.or.id/id348-catatanakhir-tahun-2013.html diakses tgl 1 September 2014.

Gronlund N. E. and Linn, R.L. (1985). Measurement and assesment in teaching (7th ed). New Jersey: Merril Englewood Cliffs.

Hake. (1999). Analyzing change/gain scores. (Online).

Tersedia http://www. physicsindiana.edu/sdi/Analyzing-Change-

Gain. pdf. Diakses Juni 2014.

Ibrahim, M. (2002). Pelatihan terintegrasi berbasis kompetensi: Pengembangan perangkat pembelajaran. Surabaya: Direktorat Sekolah Lanjutan Tingkat Pertama Departemen Pendidikan Nasional.

Ibrahim, M. (2005). Asesmen berkelanjutan. Surabaya: Universitas Negeri Surabaya.

Ibrahim, M. (2008). Model pembelajaran IPA inovatif melalui pemaknaan, Surabaya: Universitas Negeri Surabaya

Kementrian Pendidikan dan Kebudayaan, (2012). Uji Publik Kurikulum $2013 . \quad$ Jakarta: Kemendikbud.
Kesuma, D., Triatna, C., Permana, J. (2013). Pendidikan karakter kajian teori dab praktik di sekolah. Bandung: PT Remaja Rosdakarya.

Lickona, Thomas. (2013). Educating for character/mendidik untuk memberi karakter. Jakarta: Bumi Aksara

Listyarti, Retno. (2012). Pendidikan karakter dalam metode aktif, inovatif dan kreatif. Jakarta: Erlangga.

Pertiwiningrum, Agustina. (2013). Pengembangan perangkat pembelajaran berkarakter berorientasi model pembelajaran pemaknaan pada pokok bahasan sistem reproduksi manusia. Tesis Magister Pendidikan (Tidak dipublikasikan). Surabaya: Program Pascasarjana Unesa.

Priyono, Bagyo. (2013). Pengembangan perangkat pembelajaran sistem reproduksi manusia model pemaknaan untuk menumbuhkan sensitivitas moral dan sikap disiplin. Tesis Magister Pendidikan (Tesis magester tidak dipublikasikan). Surabaya: Program Pascasarjana Unesa.

Ratumanan, G.T., dan T, Laurens. (2011). Penilaian hasil Belajar pada satuan tingkat pendidikan edisi kedua. Surabaya: Unesa University Press.

Ratumanan, G.T., dan T, Laurens. (2006). Evaluasi hasil yang relevan dengan memecahkan problematika belajar dan mengajar. Bandung: CV Alfabeta.

Riduwan. (2013). Skala pengukuran variabel-variabel penelitian. Bandung: Alfabeta.

Sanjaya, H. W. (2010). Kurikulum dan pembelajaran. Jakarta: Kencana Prenada Media Group.

Sanjaya, H. W. (2012). Strategi pembelajaran berorientasi standar proses pendidikan. Jakarta: Kencana Prenada Media Group.

Sartika, Septi Budi. (2011). Pengembangan perangkat pembelajaran fisika berorientasi model pembelajaran pemaknaan. Tersedia di http://journal.Umsida ac.id/files /SeptiV1.1.pdf diakses september 2014

Slavin, Robert E. (2011). Psikologi pendidikan: teori dan praktik Jilid I Edisi kesembilan. Jakarta: PT. Indeks

Thiagarajan, S.,Semmel, D. S., Semmel. M. (1974). Instructional development for training teacher of exceptional children, a source book. Blomington: Center Of Inovation on Teaching the Handicapped Minneapolis Indiana University.

Yuliani, Nuri. (2012). Penerapan model pembelajaran pemaknaan pada pembelajaran kimia terhadap 
hasil belajar dan pengembangan karakter pada siswa SMK (Tesis Magister Pendidikan, tidak dipublikasikan). Surabaya: Program Pascasarjana Unesa
Zuriah, N. (2008). Pendidikan moral \& budi pekerti dalam perspektif perubahan. Jakarta: Bumi Aksara 